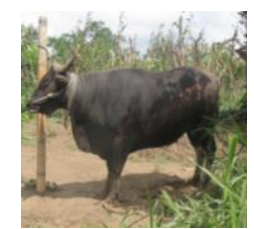

Jurnal FADET UNUD

\title{
PENGARUH PEMBERIAN PROBIOTIK MELALUI AIR MINUM TERHADAP ORGAN DALAM ITIK BALI YANG DIBERI RANSUM MENGANDUNG KULIT KECAMBAH KACANG HIJAU
}

\author{
Suwardisayoga, I M. D., N. W. Siti, dan N. M. S. Sukmawati \\ PS. Sarjana Peternakan, Fakultas Peternakan, Universitas Udayana, Denpasar, Bali \\ E-mail: dwisuwardisayoga@ @student.unud.ac.id Telp +6281237817858
}

\begin{abstract}
ABSTRAK
Penelitian ini bertujuan untuk mengetahui pengaruh pemberian probiotik melalui air minum terhadap organ dalam itik bali yang diberi ransum mengandung kulit kecambah kacang hijau. Penelitian dilaksanakan di Farm Sesetan Fakultas Perternakan Universitas Udayana, Jalan Raya Sesetan Gang Markisa no. 5 Kelurahan Sesetan, Kecamatan Denpasar Selatan, Denpasar selama 8 minggu. Rancangan yang digunakan adalah Rancangan Acak Lengkap (RAL) yang terdiri dari 3 perlakuan dan 5 kali ulangan, sehingga terdapat 15 unit percobaan. Masing-masing unit percobaan menggunakan 3 ekor itik bali betina dengan kisaran berat badan 46,98 $\pm 7,18 \mathrm{~g}$. Ketiga perlakuan tersebut adalah itik yang diberi air minum tanpa probiotik sebagai kontrol (A), itik yang diberi air minum $+2,5 \mathrm{ml}$ probiotik (B), dan itik yang diberi air minum $+5 \mathrm{ml}$ probiotik (C). Variabel yang diamati yaitu persentase jantung, hati, provetrikulus, ventrikulus, empedu, ginjal, usus halus dan panjang usus halus. Hasil penelitian menunjukkan bahwa secara umum persentase organ dalam itik yang diberi probiotik $2,5 \mathrm{ml}$ dan $5 \mathrm{ml}$ cenderung lebih tinggi dibandingkan dengan tanpa diberi probiotik (kontrol) seiring dengan meningkatnya level yang diberikan, namun secara statistik berbeda tidak nyata $(\mathrm{P}>0,05)$. Berdasarkan hasil penelitian, dapat disimpulkan bahwa pemberian probiotik melalui air minum sebanyak $2,5 \mathrm{ml}$ dan $5 \mathrm{ml} / \mathrm{ekor} / \mathrm{hari}$ pada itik yang diberi ransum mengandung kulit kecambah kacang hijau tidak berpengaruh terhadap persentase organ dalam (persentase jantung, hati, proventrikulus, ventrikulus, empedu, ginjal, usus halus dan panjang usus halus) itik bali betina umur 8 minggu.
\end{abstract}

Kata kunci: Itik bali betina, organ dalam, probiotik

\section{THE EFFECT OF GIVING PROBIOTICS THROUGH DRINKING WATER ON INTERNAL ORGANS OF BALI DUCKS THAT GIVEN RATION CONTAINING GREEN BEANS SPROUTS PEELS}

\begin{abstract}
This research aims to determine the influence of the administration of probiotics through drinking water on internal organs of bali ducks that given rations containing green bean sprouts peels. The research was carried out at the Sesetan Farm, Faculty of Animal Husbandry, Udayana University, on Jalan Raya Sesetan Gang Markisa no. 5 Sesetan, South Denpasar Sub-District for 8 weeks. The design used was a Completely Randomized Design
\end{abstract}


(CRD) consisting of 3 treatments and 5 replications,so there were 15 experimental units. Each unit used 3 female bali ducks with average body weight of $46.98 \pm 7.18 \mathrm{~g}$. The treatments were:the ducks that given drinking water without probiotics as a control (A), the ducks that given drinking water $+2.5 \mathrm{ml}$ of probiotics (B), and the ducks that given drinking water $+5 \mathrm{ml}$ of probiotics (C). The variableobserved was the percentage of heart, liver, provetriculus, ventriculus, bile, kidneys, small intestine and the long intestine. The results of this study showed that the percentage of internal organs of baliducks that given probiotics 2,5 $\mathrm{ml}$ and $5 \mathrm{ml}$ in generallytended to be higher thanthe controls, but statistically notsignificantly different ( $\mathrm{P}>$ 0.05). Based on the results of the study, it can be concluded that the administration of probiotics through drinking water as much as $2.5 \mathrm{ml}$ and $5 \mathrm{ml} /$ tail/day on the Ducks that are given rations containing the skin of green beans sprouts no effect on the percentage of internal organs (percentage of heart, liver, proventriculus, ventriculus, bile, kidney, small intestine and long intestine) females bali duck aged of 8weeks.

Key words: Bali ducks, internal organs, probiotics

\section{PENDAHULUAN}

Itik bali (Anas $s p$ ) adalah salah satu plasma nutfah ternak lokal Indonesia yang banyak dibudidayakan di daerah Bali dan Lombok. Itik bali sangat perlu dilestarikan dan dikembangkan supaya keberadaannya tidak punah (Siti, 2016). Itik bali terutama itik bali betina dapat dikembangan sebagai itik petelur dan pedaging, selain itu juga diperlukan untuk upacara agama, sehingga bagus untuk dikembangkan.

Pemeliharaan itik sudah mengarah ke sistem pemeliharaan secara intensif, dengan sistem ini kendala yang dihadapi adalah tingginya biaya pakan. Biaya pakan dapat mencapai $60 \%$ - 70\% dari total biaya produksi. Salah satu upaya untuk menekan biaya pakan adalah dengan pemanfaatan kulit kecambah kacang hijau sebagai campuran ransum.

Kulit kecambah kacang hijau adalah limbah dari pembuatan kecambah kacang hijau atau tauge, yang ketersediaannya cukup banyak. Kulit kecambah kacang hijau mengandung energi metabolisme (ME) 2841,67 kkal/kg, protein kasar 13,56\%, lemak kasar 0,22\%, serat kasar 33,07\% (Yulianto, 2010). Sehingga kulit kecambah ini potensial untuk dimanfaatkan sebagai bahan pakan ternak sumber serat, namun ternak itik tidak mampu mencerna serat dengan baik, oleh karena itu perlunya ditambahkan probiotik untuk membantu proses pencernaannya.

Probiotik adalah mikroba hidup yang menguntungkan pada makhluk hidup, yang bermanfaat untuk memperbaiki keseimbangan mikroba di dalam saluran pencernaan (Afrianto dan Liviawaty, 2005). Probiotik dapat diberikan melalui pakan atau air minum. Kelebihan dari penggunaan probiotik dalam air minum yaitu mudah dicampur dalam air dan dapat lebih mudah di serap oleh tubuh (Vidyani et al., 2015). Salah satu jenis probiotik yang dapat 
digunakan adalah dari strain Bacillus seperti Bacillus sp. dan Bacillus subtilis. Bacillus sp. strain $B T_{3} C L$ merupakan bakteri selulolitik unggul yang diisolasi dari rayap dan Bacillus subtilis strain $B R_{2} C L$ merupakan isolat bakteri selulolitik unggul asal cairan rumen sapi bali yang keduanya mempunyai kemampuan degradasi substrat/sumber yang mengandung selulosa cukup tinggi (Mudita, 2019).

Penelitian mengenai penggunaan probiotik pada ternak sudah pernah dilakukan. Dewi et al. (2019), menyatakan bahwa probiotik Effective Microorganisme-4 melalui air minum pada level $0 ; 0,5$; dan $1 \%$ tidak berpengaruh terhadap organ dalam itik bali betina umur 8 minggu (berat jantung, hati, proventrikulus, ventrikulus, empedu, ginjal, usus halus dan panjang usus halus). Mudita (2019) menyatakan bahwa probiotik yang diproduksi dari kombinasi isolat rumen sapi dan rayap mampu menghasilkan probiotik dengan populasi bakteri, kemampuan degradasi substrat, dan aktivitas enzim yang lebih tinggi daripada probiotik yang diproduksi dari satu isolat bakteri.

Berdasarkan uraian tersebut maka penelitian ini dilaksanakan untuk mengetahui pengaruh pemberian probiotik melalui air minum terhadap persentase organ dalam itik bali betina umur 8 minggu.

\section{MATERI DAN METODE}

\section{Materi}

\section{Tempat dan lama penelitian}

Penelitian ini dilaksanakan di Farm Sesetan Fakultas Peternakan Universitas Udayana, yang berlokasi di Jalan Raya Sesetan Gang Markisa no. 5 Kelurahan Sesetan, Kecamatan Denpasar Selatan, Kota Denpasar, Bali, selama 8 minggu.

\section{Ternak}

Ternak itik yang digunakan dalam penelitian ini adalah itik bali betina umur 3 hari sebanyak 45 ekor. Itik tersebut diperoleh dari peternakan itik UD. Budi Harta Utama Jl. DR. Ir. Soekarno, Kediri, Tabanan.

\section{Kandang dan perlengkapan}

Kandang yang digunakan dalam penelitian ini adalah kandang sistem "colony battery". Kandang tersebut terbuat dari kayu, bambu, dan kawat jaring sebanyak 15 petak. Setiap petak kandang memiliki ukuran panjang $80 \mathrm{~cm}$, lebar $65 \mathrm{~cm}$, tinggi $50 \mathrm{~cm}$. Alas kandang terbuat dari kawat dengan jarak dari lantai kandang $57 \mathrm{~cm}$. Semua petak kandang diletakkan pada bangunan yang berukuran $7,96 \mathrm{~m}$ x 4,98 $\mathrm{m}$ dengan atap yang terbuat dari asbes dan lantai 
beton. Setiap petak kandang dilengkapi dengan tempat pakan dari pipa paralon berukuran panjang $40 \mathrm{~cm}$ dan tempat minum dari botol bekas air mineral ukuran 1,5 liter. Pada lantai kandang diberi koran bekas agar feses dapat dibersihkan setiap tiga hari sekali untuk mengurangi aroma yang ditimbulkan oleh feses.

\section{Ransum dan air minum}

Ransum yang diberikan dalam penelitian ini tersusun dari beberapa bahan yaitu pakan dari PT. Charoen Pokphand dengan kode CP 511B dan tepung kulit kecambah kacang hijau. Air minum yang diberikan berasal dari sumur setempat dan ditambahkan probiotik sesuai dengan perlakuan. Komposisi bahan penyusun ransum dan kandungan nutrien dalam ransum dapat dilihat pada Tabel 1 dan Tabel 2.

Tabel 1. Komposisi bahan penyusun ransum pe nelitian

\begin{tabular}{lccc}
\hline \multicolumn{1}{c}{ Bahan } & \multicolumn{3}{c}{ Perlakuan $^{1)}$} \\
\cline { 2 - 4 } & $\mathrm{A}$ & $\mathrm{B}$ & $\mathrm{C}$ \\
\hline Pakan komersial CP511B (\%) ${ }^{2)}$ & 80 & 80 & 80 \\
Tepung kulit kecambah kacang hijau (\%) & 20 & 20 & 20 \\
\hline Total & 100 & 100 & 100 \\
\hline Air minum + probiotik (ml) ${ }^{1)}$ & 0 & 2,5 & 5 \\
\hline
\end{tabular}

Keterangan:

1) A : Itik yang diberi air minum tanpa probiotik sebagai kontrol

$\mathrm{B}$ : Itik yang diberiair minum $+2,5 \mathrm{ml}$ probiotik

$\mathrm{C}$ : Itik yang diberi air minum $+5 \mathrm{ml}$ probiotik

2) Produk diperoleh dari PT. Charoen Pokphand

Tabel 2. Komposisi nutrie n dalam ransum

\begin{tabular}{lccccl}
\hline \multirow{2}{*}{ Kandungan nutrien } & & \multicolumn{3}{c}{ Perlakuan $^{1)}$} & \multirow{2}{*}{ Standar $^{2)}$} \\
\cline { 3 - 5 } & & $\mathrm{A}$ & $\mathrm{B}$ & $\mathrm{C}$ & \\
\hline Energi metabolis & $(\mathrm{kka} / \mathrm{kg})$ & 2968,33 & 2968,33 & 2968,33 & Min 2700 \\
Protein kasar & $(\%)$ & 21,11 & 21,11 & 21,11 & Min 18 \\
Lemak kasar & $(\%)$ & 4,04 & 4,04 & 4,04 & 7,0 \\
Serat kasar & $(\%)$ & 10,61 & 10,61 & 10,61 & 7,0 \\
Kalsium $(\mathrm{Ca})$ & $(\%)$ & 0,72 & 0,72 & 0,72 & $0,9-1,2$ \\
Fospor $(\mathrm{P})$ & $(\%)$ & 0,48 & 0,48 & 0,48 & $0,6-1,0$ \\
\hline
\end{tabular}

Keterangan

1) A : Itik yang diberi air minum tanpa probiotik sebagaikontrol

B : Itik yang diberi air minum $+2,5 \mathrm{ml}$ probiotik

$\mathrm{C}$ : Itik yang diberi air minum $+5 \mathrm{ml}$ probiotik

2) Standar SNI 2008

\section{Kulit kecambah kacang hijau}

Kulit kecambah kacang hijau yang digunakan dalam penelitian ini diperoleh dari pedagang kecambah yang ada di Kota Denpasar. Kulit kecambah kacang hijau tersebut dibuat 
menjadi tepung untuk memudahkan dalam pencampuran ransum dan proses pencernaan dalam tubuh ternak itik.

\section{Probiotik dan te pung kulit kecambah kacang hijau}

Probiotik yang digunakan dalam penelitian ini adalah probiotik cair yang mengandung 2 bakteri yaitu Bacillus subtilis strain $B R_{2} C L$ dan Bacillus sp strain $B T_{3} C L$ yang diperoleh dari produk Mudita (2019) yang di produksi pada tahun 2019. Probiotik ini ditambahkan sebanyak 2,5 $\mathrm{ml}$ dan $5 \mathrm{ml} / \mathrm{ekor} /$ hari melalui air minum. Pembuatan tepung kulit kecambah kacang hijau dengan cara limbah kulit kecambah kacang hijau dijemur di bawah sinar matahari selama 6 jam atau hingga kering. Setelah kering, kulit kecambah kacang hijau di giling menggunakan mesin penggiling sampai halus kemudian disimpan dalam ember tertutup pada suhu ruangan.

\section{Peralatan dan perlengkapan}

Peralatan yang digunakan dalam penelitian ini, antara lain: 1) Timbangan elektrik kapasitas $5 \mathrm{~kg}$ dengan kepekaan $1 \mathrm{~g}$ yang digunakan untuk menimbang berat badan itik, bahan penyusun ransum, sisa ransum dan organ dalam; 2) Lembaran plastik untuk mencampur ransum; 3) Kantong plastik untuk tempat penyimpanan ransum yang sudah dicampur; 4) Gelas ukur berkapasitas 1 liter untuk mengukur volume air; 5) Nampan dan lembaran plastik untuk menampung air minum dan pakan yang jatuh; dan 6) Alat tulis yang digunakan untuk mencatat setiap kegiatan dari awal pemeliharaan sampai pemotongan ternak.

\section{Metoda}

\section{Rancangan penelitian}

Rancangan yang digunakan pada penelitian ini adalah Rancangan Acak Lengkap (RAL) yang terdiri dari tiga perlakuan dan lima kali ulangan. Setiap ulangan menggunakan tiga ekor itik bali betina, sehingga total itik yang digunakan adalah 45 ekor. Adapun perlakuan yang dicobakan adalah sebagai berikut:
$\mathrm{A} \quad=$ Itik yang diberi air minum tanpa probiotik sebagai kontrol
$\mathrm{B}=$ Itik yang diberi air minum $+2,5 \mathrm{ml}$ probiotik
$\mathrm{C} \quad=$ Itik yang diberi air minum $+5 \mathrm{ml}$ probiotik

\section{Pengacakan itik}

Untuk mendapatkan berat itik yang homogen, sebelum penelitian dimulai, semua itik (60 ekor) ditimbang, kemudian dicari berat badan rata-rata dan standar deviasinya. Itik yang digunakan adalah yang memiliki kisaran berat badan rata-rata \pm standar deviasi $(46,98 \pm 7,18$ 
g) sebanyak 45 ekor. Dari 45 ekor itik tersebut kemudian disebar secara acak pada 15 unit kandang, setiap unit kandang diisi 3 ekor itik.

\section{Pencampuran ransum}

Pencampuran ransum diawali dengan menyiapkan bahan-bahan ransum terlebih dahulu, kemudian ditimbang sesuai dengan perlakuan dari bahan yang komposisinya paling banyak hingga paling sedikit. Pakan yang sudah ditimbang disusun pada lembaran plastik sesuai urutan penimbangan dan selanjutnya dibagi menjadi empat bagian yang sama. Masing-masing bagian dicampur secara merata, kemudian dicampur silang dan diaduk lagi sampai rata. Campuran ransum yang sudah rata dimasukkan ke dalam kantong plastik $2 \mathrm{~kg}$. Pencampuran ransum dilakukan setiap minggu sesuai dengan kebutuhan untuk menghindari kerusakan pada ransum.

\section{Pemberian ransum dan air minum}

Ransum dan air minum diberikan ad libitum (selalu tersedia) sesuai dengan perlakuan. Penambahan ransum dilakukan apabila ketersediaannya di tempat pakan hampir habis. Sebelum diberikan air minum, probiotik di ukur sesuai perlakuan dan ditambahkan $20 \mathrm{ml}$ air minum, kemudian setelah 1-2 jam atau habis maka ditambahkan air minum secukupnya agar tetap tersedia. Tempat pakan dibersihkan setiap minggu sekali dan tempat air minum dilakukan setiap hari.

\section{Pengambilan sampel}

Pengambilan sampel dilakukan pada saat itik berumur 8 minggu. Semua itik ditimbang kemudian dicari berat rata-ratanya. Itik yang digunakan sebagai sampel diambil satu ekor dari masing-masing unit percobaan yang berat badannya memdekati berat rata-rata, sehingga jumlah itik yang dipotong adalah sebanyak 15 ekor.

\section{Prosedur pe motongan}

Sebelum dilakukan pemotongan, itik terlebih dahulu dipuasakan \pm 12 jam, akan tetapi air minum tetap diberikan, kemudian di timbang bobot badannya. Pemotongan itik dilakukan berdasarkan USDA (United State Departement of Agriculture, 1977) yaitu dengan memotong vena jugularis dan arteri carotis yang terletak antar tulang kepala dengan ruas tulang leher pertama. Darah yang keluar ditampung dengan mangkok dan ditimbang beratnya. Setelah itik dipastikan mati, kemudian dicelupkan kedalam air panas dengan suhu $\pm 65^{\circ} \mathrm{C}$ selama $1-2$ menit, selanjutnya dilakukan pencabutan bulu. 


\section{Pemis ahan organ dalam}

Pemisahan organ dalam dilakukan dengan cara membuat irisan dari kloaka ke arah tulang dada. Selanjutnya bagian dada dan perut dibelah, dan organ-organ dalam dikeluarkan. Kemudian dilakukan pemisahan seperti hati, empedu, limpa dan jantung. Isi rempela dikeluarkan, demikian pula empedu dipisahkan dari hati (Soeparno, 1992). Semua organ dalam ditimbang beratnya sesuai dengan variabel yang diamati.

\section{Variabel yang diamati}

Variabel yang diamati dalam penelitian ini adalah persentase jantung, hati, proventrikulus, ventrikulus, empedu, ginjal, dan persentase serta panjang usus halus. Cara pengukuran masing-masing variabel adalah sebagai berikut:
a. Persentase jantung $=\frac{\text { Berat jantung }}{\text { Berat potong }} \times 100 \%$
b. Persentase hati $=\frac{\text { Berat Hati }}{\text { Berat Potong }} \times 100 \%$
c. Persentase proventrikulus $=\frac{\text { Berat Proventrikulus }}{\text { Berat Potong }} \times 100 \%$
d. Persentase ventrikulus $=\frac{\text { Berat Ventrikulus }}{\text { Berat Potong }} \times 100 \%$
e. Persentase empedu $=\frac{\text { Berat Empedu }}{\text { Berat Potong }} \times 100 \%$
f. Persentase ginjal $=\frac{\text { Berat Ginjal }}{\text { Berat Potong }} \times 100 \%$
g. Persentase usus halus $=\frac{\text { Berat Usus Halus }}{\text { Berat Potong }} \times 100 \%$

h. Panjang usus halus diperoleh dengan cara mengukur panjang usus halus.

\section{Analisis statistik}

Data yang diperoleh dari hasil penelitian dianalisis dengan sidik ragam dan apabila menunjukkan perbedaan yang nyata $(\mathrm{P}<0,05)$ diantara perlakuan, maka analisis dilanjutkan dengan uji jarak berganda Duncan (Steel dan Torrie, 1993).

\section{HASIL DAN PEMBAHASAN}

Hasil analisis statistik pengaruh pemberian probiotik melalui air minum terhadap persentase organ dalam itik bali betina (persentase jantung, hati, proventrikulus, ventrikulus empedu, ginjal, usus halus dan panjang usus halus tersaji pada Tabel 3. 
Tabel 3. Pengaruh pe mberian probiotik melalui air minum terhadap persentase organ dalam dan panjang us us halus itik bali betina

\begin{tabular}{lcccc}
\hline \multirow{2}{*}{ Variabel } & \multicolumn{3}{c}{ Perlakuan ${ }^{1)}$} & \multirow{2}{*}{ SEM $^{3)}$} \\
\cline { 2 - 4 } & $\mathrm{A}$ & $\mathrm{B}$ & $\mathrm{C}$ & \\
\hline Berat potong (g/ekor) & 1320,0 & 1332,2 & 1360,2 & 23,43 \\
Persentase jantung (\%) & $0,77^{\mathrm{a} 2)}$ & $0,81^{\mathrm{a}}$ & $0,69^{\mathrm{a}}$ & 0,03 \\
Persentase hati (\%) & $1,64^{\mathrm{a}}$ & $1,71^{\mathrm{a}}$ & $1,70^{\mathrm{a}}$ & 0,08 \\
Persentase proventrikulus (\%) & $0,26^{\mathrm{a}}$ & $0,26^{\mathrm{a}}$ & $0,27^{\mathrm{a}}$ & 0,02 \\
Persentase ventrikulus (\%) & $2,62^{\mathrm{a}}$ & $2,80^{\mathrm{a}}$ & $2,81^{\mathrm{a}}$ & 0,12 \\
Persentase empedu (\%) & $0,23^{\mathrm{a}}$ & $0,20^{\mathrm{a}}$ & $0,18^{\mathrm{a}}$ & 0,03 \\
Persentase ginjal (\%) & $0,58^{\mathrm{a}}$ & $0,62^{\mathrm{a}}$ & $0,60^{\mathrm{a}}$ & 0,06 \\
Persentase usus halus (\%) & $1,32^{\mathrm{a}}$ & $1,32^{\mathrm{a}}$ & $1,29^{\mathrm{a}}$ & 0,09 \\
Panjang usus halus (cm/ekor) & $140,00^{\mathrm{a}}$ & $142,10^{\mathrm{a}}$ & $141,80^{\mathrm{a}}$ & 4,60 \\
\hline
\end{tabular}

Keterangan:

1). $A=$ Itik y ang diberi air minum tanpa probiotik sebagai kontrol

$\mathrm{B}=$ Itik yang diberi air minum $+2,5 \mathrm{ml}$ probiotik

$\mathrm{C}=$ Itik yang diberi air minum $+5 \mathrm{ml}$ probiotik

2). Nilai deng an huruf yang sama menunjukkan perbedaan yang tidak nyata $(\mathrm{P}>0,05)$.

3). SEM ( Standard Error of the Treatment Mean).

\section{Persentase jantung}

Rataan persentase jantung itik bali betina pada perlakuan A (pemberian air minum tanpa probiotik sebagai kontrol) adalah 0,77\% (Tabel 3), sedangkan pada perlakuan B (pemberian probiotik sebanyak 2,5 ml) dan perlakuan $\mathrm{C}$ (pemberian probiotik sebanyak $5 \mathrm{ml}$ ) masingmasing 5,19\% lebih tinggi dan 10,38\% lebih rendah dibandingkan dengan perlakuan A, namun secara statistik berbeda tidak nyata $(\mathrm{P}>0,05)$. Itik yang diberikan probiotik sebanyak 5 $\mathrm{ml}$ (C) persentase jantungnya 14,81\% lebih rendah dibandingkan itik yang diberikan probiotik sebanyak 2,5 ml (B) namun secara statistik berbeda tidak nyata $(\mathrm{P}>0,05)$. Hal ini disebabkan karena probiotik yang diberikan dapat membantu dalam proses metabolisme pencerna serat kasar. Pembesaran ukuran jantung biasanya diakibatkan oleh adanya penambahan jaringan otot jantung. Proses metabolisme setelah pakan masuk ke tubuh itik juga mempengaruhi aktivitas kerja jantung, dimana itik akan meningkatkan kemampuan metabolismenya untuk mencerna serat kasar sehingga ukuran jantungnya meningkat (Hetland et al., 2005). Hasil penelitian ini didukung oleh pernyataan Putnam (1991) bahwa rata-rata berat jantung itik sekitar 0,6\%-1,30\% dari berat hidup.

\section{Persentase hati}

Rataan persentase hati itik bali betina pada perlakuan A (kontrol) yang ditunjukkan pada Tabel 3 adalah 1,64\%. Pada perlakuan B dan C memiliki rataan masing-masing 4,26\% dan 3,65\% lebih tinggi dibandingkan dengan $\mathrm{A}$, dan pada perlakuan $\mathrm{C}$ memiliki rataan $0,58 \%$ lebih rendah dibandingkan dengan perlakuan $\mathrm{B}$, namun secara statistik berbeda tidak nyata 
$(\mathrm{P}>0,05)$. Hasil penelitian menunjukkan bahwa pemberian probiotik ke dalam air minum tidak menimbulkan tanda- tanda keracunan dan zat antinutrisi. Yang artinya probitik yang di berikan tidak mengandung zat-zat berbahaya yang dapat mengganggu sistem kerja hati. hasil penelitian ini lebih kecil dari hasil penelitian Putnam (1991), menyatakan bahwa persentase berat hati normal bekisar antara 1,70\%-2,80\% dari berat hidup, dan penelitian (Wiliyanti et al., 2017) menyatakan persentase hati berkisar antara 1,73-2,08\% dari berat hidup.

\section{Persentase proventrikulus}

Hasil penelitian menunjukkan bahwa persentase proventrikulus itik bali betina pada perlakuan A (kontrol) adalah 0,26\% (Tabel 3). Persentase proventrikulus pada perlakuan B memiliki nilai yang sama, sedangkan pada perlakuan C nilainaya 3,84\% lebih tinggi dibandingkan dengan kontrol. Rataan persentase proventrikulus pada perlakuan C 3,84\% lebih tinggi dibandingkan dengan perlakuan (B), namun secara statistik berbeda tidak nyata $(\mathrm{P}>0,05)$. Hal ini disebabkan oleh enzim-enzim yang di hasilkan oleh proventrikulus tidak banyak peranannya karena probiotik yang diberikan dapat membantu dalam proses menstimulasi enzim. Hasil penelitian ini didukung dengan hasil penelitian Usman (2010), yang menyatakan bahwa persentase proventrikulus mencapai $0,45 \%$ bobot hidup.

\section{Persentase ventrikulus}

Persentase ventrikulus itik bali betina tanpa pemberian probiotik (A, kontrol) adalah 2,62\% (Tabel 3). Pada perlakuan B dan C memiliki rataan 6,87\% dan 7,25\% lebih tinggi dibandingkan dengan A dan pada perlakuan $\mathrm{C}$ memiliki rataan 0,35\% lebih tinggi dibandingkan dengan perlakuan $\mathrm{B}$, namun secara statistik menunjukkan hasil berbeda tidak nyata $(\mathrm{P}>0,05)$. Pada perlakuan $\mathrm{B}$ dan $\mathrm{C}$ mendapat persentase yang lebih tinggi dari kontrol (A) Hal ini menunjukkan bahwa penggunaan probiotik pada air minum tidak dapat meringankan beban pencernaan mekanik yang dilakukan oleh ventrikulus terhadap serat kasar pada kulit kecambah kacang hijau, karena terjadinya kompetisi pada kedua bakteri yang menyebabkan tidak maksimalnya pemecahan serat kasar. Namun secara statistik berbeda tidak nyata $(\mathrm{P}>0,05)$. Hasil peneltian ini lebih kecil dari penelitian Dewi et al. (2019) yang menyatakan persentase ventrikulus berkisar antara 3,31\%-3,45\%

\section{Persentase empedu}

Penelitian ini menunjukkan bahwa persentase empedu itik bali betina pada perlakuan A (kontrol) adalah 0,23\% (Tabel 3). Pada perlakuan B dan C memiliki rataan $13,04 \%$ dan 21,73\% lebih rendah dibandingkan dengan A ( kontrol) dan pada perlakuan C memiliki 
rataan lebih rendah $10 \%$ dibandingkan dengan perlakuan $\mathrm{B}$, namun secara statistik berbeda tidak nyata $(\mathrm{P}>0,05)$. Hasil penelitian ni didukung oleh penelitian (Suda et al., 2015) yang menyatakan persentase empedu berkisar antara 0,12-0,21\% dari bobot hidup. $(\mathrm{P}>0,05)$.

\section{Persentase ginjal}

Persentase ginjal pada itik tanpa pemberian probiotik (A) adalah 0,58\% (Tabel 3) sedangkan pada perlakuan B dan C masing-masing sebesar 6,89\% dan 3,45\% lebih tinggi dari itik tanpa pemberian probiotik (A), dan pada itik perlakuan $\mathrm{C}$ memiliki rataan 3,23\% lebih rendah dibandingkan itik pada perlakuan $\mathrm{B}$, namun secara statistik berbeda tidak nyata $(\mathrm{P}>0,05)$. Hal tersebut dikarena sistem kerja hati yang tidak terganggu dan juga sedikitnya hasil metabolisme pada hati yang menyebabkan sistem kerja ginjal menjadi normal atau sama dengan kontrol.

\section{Persentase dan panjang usus halus}

Hasil penelitian menunjukkan bahwa persentase usus halus pada perlakuan $\mathrm{A}, \mathrm{B}$, dan $\mathrm{C}$ memiliki rataan yaitu $1,32 \%, 1,32 \%$, dan $1,29 \%$ dan panjang usus halus pada masing- masing perlakuan A, B, dan C memiliki rataan yaitu 140,00 cm; 142,10 cm; dan 141,80 cm yang secara statistik berbeda tidak nyata $(\mathrm{P}>0,05)$. Hal ini dikarenakan probiotik yang di berikan terdiri dari bakteri yang dapat membantu dalam proses pemecahan serat dan juga dapat membantu menekan pertumbuhan bakteri patogen. Sehingga kinerja usus menjadi ringan yang menyebabkan persentase dan panjang usus halus sama dengan kontrol (A).

\section{SIMPULAN DAN SARAN}

\section{Simpulan}

Berdasarkan hasil penelitian, dapat disimpulkan bahwa pemberian probiotik melalui air minum sebanyak $2,5 \mathrm{ml}$ dan $5 \mathrm{ml} / \mathrm{ekor} / \mathrm{hari}$ pada itik yang diberi ransum mengandung kulit kecambah kacang hijau tidak berpengaruh terhadap persentase organ dalam (jantung, hati, proventrikulus, ventrikulus, empedu, ginjal, usus halus dan panjang usus halus) itik bali betina umur 8 minggu. Dapat disarankan kepada peternak bahwa pemberian probiotik sebanyak 2,5 $\mathrm{ml}$ dan $5 \mathrm{ml}$ melalui air minum aman diberikan pada ternak itik.

\section{Saran}

Dari hasil penelitian ini, disarankan kepada peternak untuk memberikan probiotik gabungan isolat bakteri Bacillus sp. strain $\mathrm{BT}_{3} \mathrm{CL}$ dan Bacillus subtilis strain $\mathrm{BR}_{2} \mathrm{Cl}$ sebanyak $5 \mathrm{ml}$ melalui air minum karena dapat mengoptimalkan sistem kerja organ dalam. Untuk 
peneliti selanjutnya disarankan tidak menggunakan gabungan isolat bakteri Bacillus sp. strain $B T_{3} C L$ dan Bacillus subtilis strain $\mathrm{BR}_{2} \mathrm{Cl}$ yang bersifat sama karena cenderung akan terjadi kompetisi pada kedua isolat tersebut

\section{UCAPAN TERIMAKASIH}

Perkenankan penulis mengucapkan terimakasih yang sebesar-besarnya kepada Rektor Universitas Udayana Ibu Prof. Dr. dr. A. A. Raka Sudewi, Sp.S. (K), Dekan Fakultas Peternakan, Universitas Udayana Bapak Dr. Ir. I Nyoman Tirta Ariana, MS. Koordinator Program Studi Sarjana Peternakan Dr. Ir. Ni Wayan Siti, M.Si atas kesempatan dan fasilitas yang diberikan kepada penulis untuk mengikuti dan menyelesaikan pendidikan di Program Studi Sarjana Peternakan, Fakultas Peternakan, Universitas Udayana. Penulis juga menyampaikan rasa terimakasih kepada Bapak Dr. I Made Mudita, S.Pt., M.P selaku pembimbing akademik yang telah memberikan bimbingan, masukan, dan saran kepada penulis selama menempuh kuliah di Fakultas Peternakan Universitas Udayana.

\section{DAFTAR PUSTAKA}

Afrianto, E., dan Liviawaty, E. 2005. Pakan Ikan. Kanisius, Yogyakarta.

Dewi, N. M. W., Siti, N. W. dan, Sukmawati, N. M. S. 2019. Pengaruh pemberian probiotik effective microorganisme-4 melalui air minum terhadap berat organ dalam itik bali jantan. Peternakan Tropika. 7 (2): 544-558.

Hetland, H., Svihus, B., and Choctt, M. 2005."Role of insoluble fiber on gizzard activity in layers". J. Apply. Poultry Res (14):38-46.

Mudita, I. M. 2019. Penapisan dan Pemanfaatan Bakteri Lignoselulolitik Cairan Rumen Sapi Bali dan Rayap sebagai Inokulan dalam Optimalisasi Limbah Pertanian sebagai Pakan Sapi Bali. Disertasi. Program Pasca sarjana, Fakultas Peternakan, Universitas Udayana, Denpasar.

Putnam, P. A. 1991. Handbook of Animal Science. Academy Press, San Diego.

Siti, N. W. 2016. Meningkatkan Kualitas Daging Itik dengan Daun Pepaya. Penerbit Swasta Nulus, Denpasar

SNI (Standar Nasional Indonesia). 2008. Kumpulan SNI Bidang Pakan. Direktorat Budidaya Ternak Non Ruminansia, Direktorat Jenderal Peternakan, Departemen Pertanian, Jakarta.

Soeparno. 1992. Ilmu Dan Teknologi Daging. Cetakan II.Gadjah Mada University Press, Yogyakarta. 
Steel, R. G. D. and J. H. Torrie. 1993. Prinsip Dan Prosedur Statistika. Suatu Pendekatan Biometrik. Penerjemah: Sumantri, B. Gramedia Pustaka Umum, Jakarta.

Suda, I. N., Dewi, G.A.M.K., dan Wijana, I. W. 2015. Pengaruh pemberian ransum yang mengandung suplemen berprobiotik terhadap organ dalam itik bali jantan umur 8 minggu. E-Journal Peternakan Tropika. Vol. 3 No. $2: 310-323$.

USDA (United State Departement of Agriculture), 1977. Poultry Guiding Manual. U. S. Government Printing Office Washington D.C

Usman, A. N. Ramdani. 2010. Pertumbuhan Ayam Broiler (melalui sistem pencernaannya) yang Diberi Pakan Nabati dan Komersial Dengan Penambahan dysapro. Skripsi Fakultas Peternakan. Institute Pertanian Bogor, Bogor.

Vidyani, N.G.A.K.R., I N.T. Ariana, dan K.A.Wiyana. 2015. Pengaruh probiotik starbio dalam ransum komersial terhadap recahan karkas ayam broiler. Peternakan Tropika. 3 (2): $353-365$

Wiliyanti, N. K., Siti, N. W., dan Witariadi, N. M. 2017. Pengaruh Penambahan Daun Pepaya Terfermentasi dalam Ransum Terhadap Organ Dalam Itik Bali. E-journal Peternakan Tropika. Vol. 5 no. 1: 131-145

Yulianto, Joko. 2010. Pengaruh Penggunaan Kulit Kecambah Kacang Hijau Dalam Ransum Terhadap Kecernaan Bahan Kering Dan Organik Pada Kelinci Keturunan Vlaams reus Jantan. Skripsi. Program Studi Peternakan. Fakultas Pertanian, Universitas Sebelas Maret, Surakarta. 